\title{
Urgensi Pendidikan Agama Di Madrasah Dalam Membangun Kesolihan Sosial
}

\author{
Mesiono \\ Dosen Fakultas Ilmu Tarbiah dan Keguruan \\ Universitas Islam Negeri Sumatera Utara Medan \\ Email: mesiono@uinsu.ac.id
}

\begin{abstract}
Abstrak
Pendidikan agama adalah tugas semua pihak baik itu keluarga, sekolah, maupun lingkungan masyarakat. Pendidikan agama sangat utama karena bersumber dari Allah swt. melalui Alquran dan anjuran yang terdapat dalam hadis Nabi Muhammad saw. Dengan memahami nilai-nilai agama baik lewat keluarga, madrasah (sekolah) dan lingkungan diharapkan peserta didik akan memiliki aqidah yang kuat dan akhlak yang mulia sehingga tercipta kesolihan sosial. Pendidikan dan perubahan sosial saling berkaitan antara satu dengan yang lain. Keduanya saling mempengaruhi, sehingga berdampak luas di masyarakat. Pendidikan dapat dijadikan sebagai agen pembaharu atau perubahan sosial dan sekaligus menentukan arah perubahan sosial yang disebut dengan pembangunan mesyarakat. Sedangkan perubahan sosial yang terjadi dalam masyarakat setiap kalinya dapat direncanakan dengan arah perubahan yang ingin dicapai dalam membangun kesolihan sosial.
\end{abstract}

Kata Kunci: Kesolihan Sosial, Pendidikan Agama dan Madrasah.

\section{PENDAHULUAN}

Pendidikan adalah wadah atau sarana bagi setiap insane untuk mengembangkan potensi keilmuan dan pengetahuan, oleh karena itu pendidikan diharapkan memiliki konsep pendidikan dan yang berlandaskan kepada nilainilai agama. Aktivitas pendidikan baik dalam penyusunan konsep teoritis maupun dalam pelaksanaan operasionalnya harus memiliki dasar yang kokoh dengan berpedoman kepada aturan agama yaitu Alquran dan hadis.

Pendidikan agama merupakan pendidikan yang sangat urgen setiap insan tanpa terkecuali, baik secara individu maupun sosial. Pendidikan agama sangat utama karena bersumber dari Allah swt. melalui Alquran dan anjuran yang terdapat dalam hadis Nabi Muhammad saw. Dengan memahami nilai-nilai agama baik lewat keluarga, madrasah (sekolah) dan lingkungan peserta didik akan memiliki aqidah yang kuat dan akhlak yang mulia sehingga tercipta kesolihan sosial. Dengan dibekali aqidah dan akhlak yang kokoh peserta didik dapat membedakan antara perbuatan yang baik dan buruk (halal dan haram).

Pendidikan agama pada peserta didik adalah tugas semua pihak baik itu keluarga, sekolah, maupun lingkungan masyarakat. Keluarga memiliki kewajiban dalam menjaga dan membimbing anaknya ke arah yang positif karena pendidikan yang paling utama ada di dalam lingkungan keluarga. Lembaga pendidikan merupakan tempat tumbuh dan berkembangnya potensi peserta didik, mereka mencari tahu apa yang belum diketahuinya. Semua unsur dalam lembaga pendidikan harus mampu menjadi contoh teladan, dengan memperlihatkan perilaku positif sesuai dengan tuntutan agama dan akhlak yang berlaku sehingga tujuan pendidikan dapat tercapai dengan baik melalui peran lembaga pendidikan yang baik dan berkualitas dan pada akhirnya dapat mewujudkan kesolihan sosial.

\section{METODE PENELITIAN \\ Urgensi Pendidikan Agama}

Pendidikan merupakan kata yang berasal dari kata didik, yang artinya menurut Kamus Besar Bahasa Indonesia berarti: memelihara dan memberi latihan (ajaran, tuntunan, pimpinan) mengenai akhlak dan kecerdasan pikiran: Pendidikan merupakan proses pengubahan sikap dan tata laku seseorang atau kelompok orang dalam usaha mendewasakan manusia melalui upaya pengajaran dan pelatihan; proses, cara, perbuatan mendidik.

Pendidikan lebih dari sekadar pengajaran. Hal ini dikarenakan karena pendidikan adalah suatu proses dimana suatu bangsa atau negara membina dan mengembangkan kesadaran diri diantara individu-individu. Dengan kesadaran tersebut suatu bangsa atau negara dapat mewariskan kekayaan budaya atau pemikiran kepada generasi berikutnya, sehingga menjadi inspirasi bagi mereka dalam setiap aspek kehidupan.

Sementara itu kata agama berasal dari bahasa Sansakerta, asal katanya bersumber dari kata "Gam" yang artinya pergi, setelah mendapat awalan " $a$ " dan akhiran adalah " $a$ " yang memiliki arti jalan. Sedangkan dalam kamus bahasa Indonesia agama bermakna segenap kepercayaan kepada Tuhan Yang Maha Esa dan sebagainya dengan kebaktian dan kewajiban-kewajiban yang bertalian dengan kepercayaan itu. 
Pendidikan agama adalah penunjuk arah dalam kehidupan. Perkembangan masyarakat yang begitu cepat dan semakin dinamis sebagai akibat kemajuan ilmu dan teknologi, terutama teknologi informasi, maka aktualisasi nilai-nilai agama menjadi sangat penting. Karena tanpa aktualisasi agama ini, umat Islam akan menghadapi kendala dalam upaya internalisasi nilai-nilai dalam Alquran dan hadis sebagai upaya pembentukan pribadi umat yang beriman, bertaqwa, berakhlak mulia, cerdas, maju dan mandiri.

Kedudukan pendidikan agama dalam Undang-undang No. 20 Tahun 2003menjelaskan tentang fungsi dan tujuan pendidikan nasional yaitu mengembangkan kemampuan dan membentuk watakserta peradaban bangsa, bertujuan untuk perkembangan potensi peserta didik menjadi manusia berimandan bertakwa kepada Tuhan yang Maha Esa, berakhlak mulia, sehat, berilmu, kereatif serta bertanggung jawab.

Berangkat dari kehidupan modern dengan kehebatan ilmu pengetahuan dan teknologi serta kemajuan ekonomi yang dialami bangsa-bangsa ternyata menimbulkan berbagai kehidupan suasana yang tidak memberikan kebahagiaan bathiniah dan rasa kehampaan. Sehingga berkembang kecenderungan untuk menata kehidupan yang berlandaskan nilai-nilai spritual. Nilai-nilai spritual adalah nilai-nilai yang terkandung dalam nilai-nilai agama yang perlu diterpakan dalam kehidupan sehari-hari sehingga terbangun kesolihan sosial.

Pendidikan Agama sangat urgen dalam membangun kesuksesan kehidupan dunia dan akhirat. Melihat begitu pentingnya pendidikan agama, banyak ormas Islam yang berusaha membangun lembaga pendidikan Islam untuk mendukung pendidikan agama yang baik. Hasan Bakti Nasution menuliskan bahwa hampir semua ormas Islam melakukan pemberdayaan umat melalui pendidikan. Hal ini dikarenakan memang bidang ini menjadi kebutuhan primer umat. Di sampng itu, terdapat dorongan yang begitu kuat dari ajaran Islam agar menuntut ilmu, sehingga dikategorikan sebagai kewajiban individual. Maraknya kebodohan dan rendahnya kualitas pendidikan, menjadi dasar utama mengapa pendidikan menjadi tujuan utama ormas 1slam. Muhammadiyah, Al-Ittihadiyah, Nahdhatul Ulama, Al-Washliyah, dan ormasormas Islam lainnya adalah diantara organisasi Islam yang sangat konsentrasi dalam upaya menggerakkan kemajuan pendidikan agama umat Islam melalui lembaga-lembaga pendidikan yang telah dimilikinya.

Keberadaan lembaga pendidikan lslam yang dikelola oleh organisasi keagamaan, seperti Al-Ittihadiyah di Indonesia benar-benar telah menunjukkan eksistensinya dan memberikan harapan yang besar untuk dapat berperan aktif, kreatif dan positif dalam pembentukan pribadi bangsa. Dalam prosesnya lembaga pendidikan Al-Ittihadiyah harus mampu menciptakan sumber daya manusia yang memiliki kekuatan moral, etika dan spritual dalam membangun bangsanya terutama dalam memasuki era globalisasi atau abad ke-21. Hal ini juga telah dilakukan oleh organisasiorganisasi keagamaan lainnya seperti Muhammadiyah, Nahdhatul Ulama, AlWashliyah dan organisasi Islam lainnya yang memiliki peran besar dalam membangun pendidikan agama yang dibutuhkan masyarakat melalui lembaga pendidikan yang dikelolanya. Semua organisasi Islam berupaya untuk berpartisipasi membangun dan mendukung kesuksesan pendidikan agama untuk membangun kesolihan sosial.

Pendidikan agama dalam merupakan proses pembentukan pribadi muslim dengan menanamkan pengetahuan dan nilai-nilai Islam sehingga terbentuk insan islami yang sempurna baik dari segi akal, jasmani dan rohani untuk beramal di dunia dan meraih kesuksesan di akhirat. Tujuan tertinggi dalam pendidikan islami adalah menciptakan manusia Muslim yang bershahadah kepada Allah swt. Pendidikan islami akan mengarahkan untuk memberi bantuan kemudahan dalam mengembangkan potensi jasmaniyah dan ruhaniyah dapat mengaktualisasikan syahadahnya terhadap Allah swt. Hal ini menunjukkan bahwa pendidikan agama sangat urgen dan tidak bisa ditawar-tawar.

Manusia tidak bias dilepaskan dari agama karena makhluk beragama. Agama pada hakekatnya tidak dapat dipisahkan dari kehidupan manusia, namun karena faktor pengaruh lingkungan, baik lingkungan keluarga, maupun lingkungan sosial yang begitu luas termasuk lingkungan sekolah dan masyarakat, seseorang bisa saja tidak mau melaksanakan ajaran agama dan bahkan terkadang ada yang atheis yaitu tidak meyakini agama sama sekali. Kekhawatiran dalam mengikisnya nilai-nilai agama sehingga berbagai elemen berusaha untuk berpartisipasi membangun pendidikan agama sehingga tercipta kesolihan sosial.

Pendidikan agama sangat urgen dalam kehidupan beragama, berbangsa dan bernegara. Hal ini terbukti dari sisi berbagai sendi sejarah pasca kemerdekaan Indonesia diproklamirkan, maka selanjutnya pada tanggal 18 Agustus 1945 ditetapkannya asas yang menempatkan Ketuhanan Yang Maha Esa sebagai sila pertama dari Pancasila, sebagai manifestasi dari sikap hidup yang religius tersebut. Selain itu gambaran keberagamaan terdapat pada pasal 29 
UUD 1945 yang menjelaskan bahwa pada ayat 1 dikatakan "Negara berdasarkan atas Ketuhanan Yang Maha Esa". Kemudian dilanjutkan ayat 2 dikatakan bahwa "Negara menjamin kemerdekaan tiap-tiap penduduk untuk memeluk agamanya masing-masing dan beribadat menurut agama dan kepercayaannya itu". Hal ini menunjukkan bahwa sesungguhnya agama adalah bagian yang tidak terpisahkan dalam kehidupan insan Indonesia.

Pada tahun 1960 pendidikan agama di sekolah-sekolah di Indonesia mulai mendapat status yang semakin kuat. Ketetapan MPR S No. II/MPRS/1960 Bab II pasal 2 ayat 3 menetapkan pendidikan agama diajarkan mulai dari Sekolah Rakyat sampai universitasuniversitas Negeri. Pendidikan agama merupakan salah satu dari tiga subyek pelajaran yang harus dimasukkan dalam kurikulum setiap lembaga pendidikan formal di Indonesia. Hal ini karena kehidupan beragama merupkan salah satu dimensi kehidupan yang diharapkan dapat terwujud secara terpadu.

Usaha pendidikan dalam rangka membangun insan Indonesia seutuhnya, memberikan arti bahwa perlunya pengembangan dimensi aspek kepribadian secara seimbang dan merata. Konsep manusia seutuhnya harus dipandang memiliki unsur jasad, akal, dan kalbu serta aspek kehidupannya sebagai makhluk individu, sosial, susila, dan agama. Kesemuanya harus berada dalam kesatuan integrlistik yang menyatu. Pendidikan agama perlu diarahkan untuk mengembangkan iman, akhlak, hati nurani, budi pekerti serta aspek kecerdasan dan keterampilan sehingga terwujud keseimbangan. Pendidikan agama secara langsung akan mampu memberikan kontribusi terhadap seluruh dimensi perkembangan insan Indonesia seutuhnya seperti tercermin dari semua unsur yang terkandung dalam rumusan tujuan pendidikan nasional seperti yang dimaksudkan.

Pendidikan agama harus diperkokoh. Dalam pelaksanaan pendidikan, khususnya pendidikan agama yang objeknya adalah pribadi peserta didik yang sedang berkembang, maka adanya hubungan timbal balik antara penanggung jawab pendidikan, yaitu yang di dalamnya terdiri dari kepala madrasah (sekolah), para guru, staf ketatausahaan, orang tua dan anggota keluarga lainnya mutlak diperlukan. Hal ini bukan hanya karena peserta didik masih memerlukan perlindungan dan bimbingan madrasah (sekolah) dan keluarga tersebut, tetapi juga pengaruh pendidikan dan perkembangan kejiwaan yang diterima peserta didik dari kedua lingkungan tersebut tidak boleh menimbulkan pecahnya kepribadian anak.
Semua unsur sepakat bahwa pendidikan agama sangat penting. Setiap satuan pendidikan wajib menyelenggarakan pendidikan agama. Adapun diantara ketentuannya yaitu sebagai berikut:

a. Setiap satuan pendidikan menyediakan tempat menyelenggarakan pendidikan agama yang layak dan seuai standart.

b. Satuan pendidikan yang tidak dapat menyediakan tempat menyelenggarakan pendidikan agama dapat bekerja sama dengan satuan pendidikan yang setingkat atau penyelenggaraan pendidikan agama di masyarakat untuk menyelenggarakan pendidikan agama bagi peserta didik, sehingga menjaga kualitas dan profesionalitas.

c. Satuan pendidikan seharusnya menyediakan tempat dan kesempatan kepada peserta didik untuk melaksanakan ibadah berdasarkan ketentuan persyaratan agama yang dianut oleh peserta didik, sehingga peserta didik dapat mengaplikasikan nilai-nilai pendidikan agamanya.

d. Tempat melaksanakan ibadah agama dapat berupa ruangan di dalam atau di sekitar lingkungan satuan pendidikan yang dapat digunakan peserta didik menjalankan ibadahnya, sehingga pendidikan agama bukan hanya sekedar teori tetapi upaya dalam membangun kesolihan sosial.

Adapun tujuan pendidikan agama, yaitu untuk berkembangnya kemampuan peserta didik dalam mengembangkan, memahami, menghormati dan mengamalkan nilai-nilai agama, penguasaan ilmu pengetahuan, teknologi dan seni. Dalam pelaksanaan pendidikan agama harus memerhatikan prinsip dasar yang urgen, diantaranya yaitu sebagai berikut:

a. Pelaksanaan pendidikan agama harus mengacu pada kurikulum pendidikan agama yang berlaku sesuai dengan agama yang dianut peserta didik, tidak memaksakan pendidikan agama kepada pemeluk agama lain.

b. Pendidikan agama harus mendorong peserta didik untuk taat menjalankan ajaran agamanya dalam kehidupan sehari-hari dan menjadikan agama sebagai landasan etika dan moral dalam berbangsa dan bernegara, bukan hanya sekedar teori dan tinggal di lembarab buku catatan.

c. Pendidikan agama harus dapat menumbuhkan sikap kritis, kreatif, inovatif, dan dinamis sehingga menjadi 
pendorong peserta didik untuk menguasai ilmu pengetahuan, teknologi, dan seni sehingga dapat terlihat jelas agama adalah rahmatan lil'alamin.

d. Pendidikan agama harus mampu mewujudkan keharmonisan, kerukunan, dan rasa hormat internal agama yang dianut dan terhadap pemeluk agama lain, sehingga Nampak jelas kesolihan sosial dengan saling menghargai dan menyayangi.

e. Satuan pendidikan yang berciri khas agama dapat menciptakan suasana keagamaan dan menambah muatan pendidikan agama sesuai kebutuhan, seperti tambahan materi, jam pelajaran, dan kedalamannya. Pola inilah yang digunakan oleh madrasah dan pesantren, sehingga memaksimalkan pendidikan agama yang tujuannya adalah untuk memperdalam pengetahuan agama.

Pendidik pendidikan agama pada satuan pendidikan disediakan oleh satuan pendidikan yang bersangkutan atau disediakan oleh pemerintah atau pemerintah daerah. Mengenai pengawasan pendidikan agama dilakukan oleh pengawas pendidikan agama terhadap penyelenggaraan pendidikan agama, yang meliputi pemantauan, supervisi, evaluasi, pelaporan, dan tindak lanjut hasil pengawasan. Laporan sebagaimana dimaksud di atas berisi evaluasi terhadap pelaksanaan teknis pendidikan agama dan ditujukan kepada Kantor Departemen Agama Kabupaten/Kota atau Kantor Wilayah Departemen Agama.

Ahmad Tafsir menjelaskan pendidikan agama Islam (PAI) dibakukan sebagai nama kegiatan dalam mendidikkan agama Islam. Sebagai mata pelajaran namanya adalah "agama Islam". Usaha-usaha dalam mendidikkan agama Islam itulah yang disebut sebagai "pendidikan agama Islam". Dalam hal ini PAI sejajar atau sekategori dengan mata pelajarannya, yang penting diperhatikan disini ialah pendidikan Islam adalah nama sistem, dan pendidikan agama Islam adalah nama kegiatan (dalam mendidikkan agama Islam kepada siswa). Diharapkan dalam pendidikan agama yang diajarkan di madrasah atau lembaga pendidikan Islam lainnya dapat membangun kesolihan sosial.

\section{HASIL dan PEMBAHASAN Madrasah}

Madrasah secara bahasa berarti tempat untuk belajar. Kata lain Madrasah dalam bahasa Indonesia adalah "sekolah", dengan maksud yang khusus yaitu sekolah-sekolah agama Islam. Tempat belajar adalah tempat untuk mengajarkan dan mempelajari sesuatu termasuk ajaran-ajaran agama Islam, ilmu pengetahuan, dan keahlian lainnya yang berkembang pada zamannya.

Eksistensi madrasah di Indonesia sebagai lembaga pendidikan Islam. Madrasah terdiri atas Ibtidaiyah (dasar), madrasah Tsanawiyah (sekolah menengah pertama) dan madrasah Aliyah (sekolah menengah atas), dimana madrasah telah memberikan kontribusi yang sama dengan sekolah umum lainnya dalam mencerdaskan kehidupan bangsa.

Kehadiran madrasah sebagai lembaga pendidikan dilatarbelakangi oleh munculnya semangat pembaharuan pendidikan Islam di Indonesia. Madrasah sebagai lembaga pendidikan yang muncul setelah pesantren dan sekolah mengadopsi sebagian sistem pesantren dan sekolah. Dijelaskan secara eksplisit madrasah adalah sekolah yang berciri khas agama Islam, makna yang terkandung di dalamnya bahwa madrasah mulai dari tingkat dasar dan menengah memberlakukan kurikulum ilmu-ilmu agama sebagai ciri khasnya.

Madrasah adalah salah satu institusi pendidikan Islam yang penting di Indonesia. Muncul di akhir abad kesembilan belas, pada periode awal perkembangannya, madrasah cenderung bersaing dengan pendidikan Belanda yang ditawarkan oleh pemerintah kolonial dan menjadi simbol reformasi Islam. Madrasah adalah institusi pendidikan Islam yang mengajar mata pelajaran Islam dan sekuler, menggunakan sistem penilaian, dan menawarkan sertifikat kepada lulusannya. Dalam konteks Indonesia, madrasah terletak antara pesantren dan sekolah (sekolah umum).

Secara historis, pada tahap-tahap awal pembelajaran madrasah tidaklah langsung strategis, awal mula yang dikehendaki dari madrasah ini adalah suatu lembaga pendidikan dengan sistem klasikal, yang di dalamnya anak didik mendapatkan ilmu pengetahuan agama dan umum secara berimbang. Tetapi pada prakteknya, hanya dicerminkan oleh sistem klasikalnya saja, sementara kurikulum yang diajarkan tetap semata-mata bidang studi agama. Karena itu banyak madrasah pada tahaptahap awal ini tidak bedanya dengan pesantren tradisional yang sudah lama berjalan.

Secara resmi di sekolah-sekolah umum pada masa penjajahan Belanda belum diberikan pendidikan agama. Sekitar abad ke-19, pemerintah Belanda mulai memperkenalkan sekolah-sekolah modern yang berkembang di dunia barat sehingga hal itu sedikit banyak mempengaruhi bagaimana pola sistem pendidikan yang telah berkembang di Indonesia, 
termasuk pesantren yang menjadi sistem pendidikan madrasah. Hal ini menunjukkan bahwa sistem sekolah yang dikembangkan oleh pemerintah kolonial Belanda telah memasuki dunia pesantren. Sistem khalaqah bergeser ke arah sistem madrasah dalam bentuk klasikal, dengan unit-unit kelas.

Pada perkembangan selanjutnya, banyak madrasah yang didirikan terpisah dengan induknya yaitu pesantren, surau atau masjid. Dengan adanya ide-ide pembaruan dalam dunia pendidikan Islam di Indonesia, tidak sedikit madrasah yang didirikan sudah lepas sama sekali dengan pesantren sehingga tidak hanya memberikan pengetahuan agama, tetapi juga mengajarkan pengetahuan umum, sesuai dengan tuntutan zaman. Madrasah yang pertama kali didirikan di Indonesia adalah Madrasah Adabiyah di Padang Sumatra Barat, yang didirikan oleh Syekh Abdullah Ahmad tahun 1909. Madrasah tersebut pada mulanya bercorak agama murni. Akhirnya pada tahun 1915 berubah coraknya menjadi HIS (Holand Inland School) Adabiyah. HIS Adabiyah inilah yang merupakan sekolah pertama yang memasukkan pelajaran agama ke dalam kegiatan pengajarannya.

Dalam perkembangannya, kurikulum pada madrasah dari waktu ke waktu senantiasa mengalami perkembangan dan perubahan seiring dengan kemajuan zaman. Semua ini dilakukan adalah dengan tujuan peningkatan kualitas madrasah, agar keberadaannya tidak diragukan dan sejajar dengan sekolah-sekolah lain.

Jumlah madrasah yang cukup besar di Indonesia memberikan andil yang besar dalam ikut serta mencerdaskan kehidupan bangsa. Namun, ciri khas madrasah yang menitikberatkan pendidikan agama (mula-mula $100 \%$ agama kemudian $70 \%$ agama dan $30 \%$ umum), dipandang kurang mampu membekali peserta didik untuk bisa hidup di dunia yang semakin maju, yang membutuhkan penguasaan iptek untuk menghadapinya. Lulusan madrasah kurang bersaing di bidang penggunaan iptek dibandingkan anak-anak lulusan sekolah umum. Padahal, orang memerlukan kehidupan yang layak dan bersaing dengan lulusan sekolah yang lain.

Pemerintah berusaha untuk meningkatkan mutu madrasah agar sejajar dengan sekolah umum yang setingkat. Usaha itu diwujudkan dengan keluarnya Surat Keputusan Bersama Tiga Menteri yang kemudian dikenal dengan SKB 3 M. yang dimaksud dengan SKB $3 \mathrm{M}$ yaitu keputusan bersama antara Menteri Agama dengan SK No. 6 Tahun 1975, Menteri Pendidikan dan Kebudayaan dengan SK No. 37/U/1975 dan Menteri Dalam Negeri dengan
SK No. 36 Tahun 1975, tertanggal 24 Maret 1975 tentang Peningkatan Mutu Madrasah.

Yang dimaksud dengan madrasah SKB $3 \mathrm{M}$ yaitu lembaga pendidikan yang menjadikan mata pelajaran agama Islam sebagai mata pelajaran dasar yang diberikan sekurangkurangnya $30 \%$ disamping mata pelajaran umum. Sedangkan sebelum SKB $3 \mathrm{M}$, komposisi kurikulum madrasah yaitu70\% pelajaran agama dan $30 \%$ pelajaran umum.

Dengan adanya SKB 3 Menteri tersebut, bukan berarti beban yang dipikul madrasah tambah ringan, akan tetapi justru sebaliknya. Hal ini dikarenakan, disatu pihak ia dituntut untuk mampu memperbaiki kualitas pendidikan umum sehingga setaraf dengan standar yang berlaku disekolah umum, dilain pihak ia harus menjaga agar mutu pendidikan agama tetap baik sebagai ciri khasnya. Oleh karena itu, untuk mencapai kedua tujuan dimaksud, sudah barang tentu harus diadakan peninjauan kembali terhadap kurikulum yang berlaku, materi pelajaran, sistem evaluasi dan peningkatan mutu tenaga pengajaran melalui penataran-penataran.

Madrasah baik Ibtidaiyah, Tsanawiyah maupun Aliyah merupakan salah satu unsur pendidikan nasional mempunyai peranan yang cukup penting dalam upaya mencapai tujuan pendidikan nasional terutama dalam mewujudkan manusia dan masyarakat Indonesia yang beriman dan bertaqwa kepada Allah swt. serta berakhlak mulia. Keadaan ini menjadi lebih penting lagi mengingat peran madrasah adalah mempersiapkan sumber daya manusia yang tangguh guna memasuki era otonomi daerah dan otonomi pendidikan yang berlandaskan nilai-nilai agama.

Keberadaan madrasah sebagai lembaga pendidikan Islam tidak akan lepas dari persaingan global tersebut. Untuk itu peningakat kualitas merupakan agenda utama dalam meningkatkan mutu madrasah agar dapat terus berkembang dalam era global. Madrasah harus memiliki visi yang jelas dalam membangun kemajuan umat. Adapun visi dari madrasah dan pendidikan agama Islam adalah terwujudnya manusia yang bertaqwa, berakhlak mulia, berkepribadian, berilmu, terampil dan mampu mengaktualisasikan diri dalam kehidupan bermasyarakat.

Visi madrasah akan lebih jelas dengan misinya yaitu menciptakan lembaga yang islami dan berkwalitas, menjabarkan kurikulum yang mampu memahami kebutuhan anak didik dan masyarakat, menyediakan tenaga kependidikan yang profesional dan memiliki kompotensi dalam bidangnya dan menyelenggarakan proses pembelajaran yang menghasilkan lulusan yang berprestasi. 
Madrasah yang unggul adalah madrasah yang memiliki kurikulum yang unggul. Kurikulum pada madrasah dari waktu kewaktu senantiasa mengalami perkembangan dan perubahan seiring dengan kemajuan zaman. Semua ini dilakukan adalah dengan tujuan usaha dan ikhtiar peningkatan kualitas madrasah, agar keberadaanya tidak diragukan dan sejajar bahkan lebih unggul dari lembagalembaga pendidikan lainnya.

Selain madrasah lembaga pendidikan lain yang konsentrasi kepada pendidikan agama adalah pesantren. Pesantren adalah salah satu lembaga yang unik dengan ciri-ciri khas yang sangat kuat dan lekat. Peran yang diambil adalah upaya-upaya pencerdasan bangsa yang telah turun temurun tanpa henti. Pesantren telah memberikan pendidikan pada masa-masa sulit, masa perjuangan melawan kolonial dan merupakan pusat studi yang tetap survive sampai masa kini. Tujuan pendidikan pesantren menanamkan nilai-nilai agama.

Menurut Manfred Ziemek asal kata pesantren adalah "pe-santri-an" yang artinya tempat santri. Jadi pesantren adalah tempat para santri untuk menuntut ilmu (Agama Islam). Soegarda menjelaskan bahwa pesantren asal katanya adalah santri, yaitu seorang yang belajar agama Islam. Kemudian Prof. Johns berpendapat bahwa istilah santri berasal dari bahasa Tamil yang berarti guru mengaji.

Keberadaan pesantren merupakan lembaga pendidikan Islam tertua di Indonesia. Pesantren difungsikan sebagai suatu lembaga yang dipergunakan untuk penyebaran agama dan tempat mempelajari agama Islam. Pesantren juga mengusahakan pembinaan tenaga-tenaga bagi pengembangan agama. Pesantren adalah lembaga yang bisa dikatakan merupakan wujud proses perkembangan sistem pendidikan nasional.

Secara garis besar, tipologi pesantren bisa dibedakan paling tidak menjadi tiga jenis, walaupun agak sulit untuk membedakan secara ekstrim diantara tipe-tipe tersebut yaitu salafiyah (tradisional), khalafiyah (modern) dan terpadu.

Berdasarkan kurikulum atau sistem pendidikan yang dipakai, pesantren mempunyai tiga tipe, yaitu:
a. Pesantren Tradisional (salaf)
b. Pesantren Modern (khalaf)
c. Pesantren Komprehensif.

Karakteristik atau ciri-ciri umum pondok pesantren yang sangat dikenal di masyarakat diantaranya adalah:
a. Adanya kiai,
b. Adanya santri,
c. Adanya masjid,
d. Adanya pondok atau asrama.

Pesantren adalah sebuah kawasan yang khas yang ciri-cirinya tidak dimiliki oleh kawasan yang lain. Karenanya tidak berlebihan jika Abdurrahman Wahid menyebut sebagai sub-kultur tersendiri. Adapun unsur-unsur yang terdapat dalam sistem pendidikan pesantren secara tradisional yang menjadikannya khas adalah kiai, santri, masjid, pondok dan pengajaran kitab-kitab klasik.

Sistem yang ditampilkan dalam pondok pesantren mempunyai keunikan dibandingkan dengan sistem yang diterapkan dalam lembaga pendidikan pada umumnya, yaitu:

a. Memakai sistem tradisional, yang memiliki kebebasan penuh dibandingkan dengan sekolah modern, sehingga terjadi hubungan 2 arah antara kiai dan santri.

b. Kehidupan dipesantren menampakkan semangat demokrasi, karena mereka praktis bekerjasama mengatasi problem non kurikuler mereka sendiri.

c. Para santri tidak mengidap penyakit simbolis, yaitu perolehan gelar dan ijazah, karena sebagian besar pesantren tidak mengeluarkan ijazah, sedangkan santri dengan ketulusan hatinya masuk pesantren tanpa adanyaijazah tersebut. Hal itu karena tujuan utama mereka hanya ingin mencari keridhoan Allah swt. semata.

d. Sistem pondok pesantren mengutamakan kesederhanaan, idealisme, persaudaraan, persamaan, rasa percaya diri, dan keberanian hidup.

e. Alumni pondok pesantren tak ingin menduduki jabatan pemeritahan, sehingga mereka hampir tidak dapat dikuasai oleh pemerintah.

Menurut M. Arifin bahwa tujuan didirikannnya pendidikan pesantren pada dasarnya terbagi pada dua yaitu:

a. Tujuan Khusus, yaitu mempersiapkan para santri untuk menjadi orang 'alim dalam ilmu agama yang diajarkan oleh Kyai yang bersangkutan serta mengamalkannya dalam masyarakat.

b. Tujuan Umum, yakni membimbing anak didik agar menjadi manusia yang berkepribadian Islam yang sanggup dengan ilmu agamanya menjadi mubaligh Islam dalam masyarakat sekitar dan melalui ilmu dan amalnya.

Berdasarkan uraian yang dikemukan di atas dapat dipahami bahwa lembaga-lembaga pendidikan Islam memiliki peran strategis dalam membangun dan menjaga kualitas pendidikan agama. Dengan pendidikan agama 
yang tetap dijaga dan dilestarikan di lembagalembaga pendidikan Islam baik madrasah, pesantren dan lembaga pendidikan lainnya diharapkan nilai-nilai pendidikan agama dapat terealisasi sehingga terbentuk kesolihan sosial melalui peran lembaga pendidikan.

\section{Perkembangan Pendidikan Agama Lembaga Pendidikan Islam}

Sistem pendidikan di Indonesia adalah yang terbesar keempat di dunia. Meskipun data tentang jumlah sebenarnya sekolah Islam (Madrasah dan pesantren) di Negara ini berbeda. Dapartemen Agama mengklaim mengelola sekitar 45.000 pada tahun 2010 . Lebih dari 90 persen diantaranya adalah sekolah swasta, banyak diantaranya didirikan oleh masyarakat setempat. Lembaga tersebut mengumpulkan atau menyerap 6 juta siswa terdiri dari 3,5 juta siswa dari 22.000 sekolah dasar Islam (Madrasah Ibtibtidaiyah) dan 2,5 juta siswa di 14.000 Madrasah Tsanawiyah. Diantara jumlah tersebut termasuk jumlah lembaga pendidikan yang dikelola oleh organisasi Islam seperti Muhammadiyah, AlIttihadiyah, Al-Washliyah dan organisasi Islam lainnya.

Dalam realitas sejarahnya, pengembangan kurikulum pendidikan agama Islam (PAI), ternyata mengalami perubahan-perubahan paradigma, walaupun dalam beberapa hal tertentu paradigma sebelumnya masih tetap dipertahankan hingga sekarang. Hal ini dapat dicermati dari berbagai fenomena, diantaranya yaitu sebagai berikut:

a. Perubahan dari tekanan hafalan dan daya ingatan tentang teks-teks dari ajaran-ajaran agama Islam, serta disiplin mental spiritual sebagaimana pengaruh dari Timur Tengah, kepada pemahaman tujuan, makna dan motivasi beragama Islam untuk mencapai tujuan pembelajaran PAI.

b. Perubahan dari cara berfikir tekstual, normatif dan absolutis kepada cara berpikir historis, empiris dan kontekstual dalam memahami dan menjelaskan ajaran dan nilai-nilai agama Islam.

c. Perubahan dari tekanan pada produk atau hasil pemikiran keagamaan Islam dari para pendahulunya kepada proses atau metodologinya sehingga menghasilkan produk tersebut.

d. Perubahan dari pola pengembangan kurikulum PAI yang hanya mengandalkan pada para pakar dalam memilih dan menyusun isi kurikulum PAI ke arah keterlibatan yang luas dari para pakar, guru, peserta didik, masyarakat untuk mengidentifikasi tujuan PAI dan cara-cara mencapainya.

Dengan adanya tranformasi, baik kultur, sistem dan nilai yang ada di pondok pesantren, maka kini pondok pesantren yang dikenal dengan salafiyah kini telah berubah menjadi khalafiyah (modern). Transformasi tersebut sebagai jawaban atas kritik-kritik yang diberikan pada pesantren dalam arus transformasi ini, sehingga dalam sistem dan kultur pesantren terjadi perubahan yang drastis, misalnya

a. Perubahan sistem pengajaran dari perseorangan atau sorogan menjadi sistem klasikal yang kemudian kita kenal dengan istilah madrasah (sekolah).

b. Pemberian pengetahuan umum disamping masih mempertahankan pengetahuan agama dan bahasa arab.

c. Bertambahnya komponen pendidikan pondok pesantren, misalnya keterampilan sesuai dengan kemampuan dan kebutuhan masyarakat, kesenian yang islami.

d. Lulusan pondok pesantren diberikan syahadah (ijazah) sebagai tanda tamat dari pesantren tersebut dan ada sebagian syahadah tertentu yang nilainya sama dengan ijazah negeri.

Lembaga pendidikan Islam tidak hanya dituntut memenuhi kebutuhan masyarakat Indonesia, tetapi sekaligus harus mampu mengantisipasi tantangan global. Oleh sebab itu, banyak perubahan yang terjadi di lembaga pendidikan Islam seperti madrasah dan pesantren. Pesantren sekarang lebih terbuka dibandingkan sebelumnya yang awalnya tertutup seperti melarang bahasa Inggris (karena menganggap bahasa kafir) dan tidak boleh belajar komputer sekarang bahkan ada yang memiliki keunggulannya sains dan teknologi seperti pesantren Darul Mursyid.

Madrasah dewasa ini disipkan dengan kurikulum lengkap. Madrasah bukan hanya didominasi pelajaran agama saja, tetapi juga dilengkapi kurikulum pelajaran umum serta ekstra kurikuler yang dibutuhkan masyarakat sehingga lulusan madrasah dapat bersaing dengan lulusan lembaga pendidikan umum di masyarakat, bahkan dapat berkompetisi untuk masuk ke perguruan tinggi pavorit. Dengan disiapkannya lembaga-lembaga pendidikan Islam yang menguasi berbagai disiplin ilmu diharapkan dapat memaksimalkan fungsi pendidikan agama sehingga terbangun dengan baik kesolihan sosial. 


\section{Peran Pendidikan Islam dalam Membangun Kesolihan Sosial}

Kesolihan berasal dari kata bahasa Arab 'solih' yang memiliki makna baik. Adapun pengertian sosial berasal dari kata latin sociates, yang mempunyai arti masyarakat. Pendapat lain mengatakan bahwa pengertian sosial adalah hubungan seorang individu dengan yang lainnya dari jenis yang sama; atau pada sejumlah individu yang yang membentuk lebih banyak atau lebih sedikit kelompok-kelompok yang terorganisir, juga tentang kecenderungankecenderungan dan impuls-impuls yang berhubungan denganyang lainnya.

Dalam melaksanakan pendidikan sosial diharapkan akan tercapai sebuah tujuan yang dicita-citakan yaitu adanya manusia yang tanggap serta peduli terhadap masalah-masalah yang terjadi di lingkungan sekitarnya dan dengan adanya tujuan tersebut dapat membangkitkan semangat untuk berbuat kesolihan sosial. Nilai-nilai kebaikan ini merupakan bagian penting dari pendidikan, lebih tepatnya pendidikan yang mengarahkan pada kepedulian sosial atau dalam istilah pendidikan sering disebut dengan pendidikan sosial.

Pentingnya pendidikan sosial ditanamkan dengan kokoh di lembaga pendidikan karena dalam kehidupan ini banyak terjadi hal-hal yang tidak sesuai dengan norma-norma yang berlaku. Pendidikan sosial melibatkan bimbingan terhadap tingkah laku sosial, ekonomi dan politik dalam mengimplementasikan pendidikan Islam yang diharapkan dapat meningkatkan iman, taqwa, takut kepada Allah dan mengerjakan ajaran-ajaran agama serta mendorong pada produksi, menghargai waktu, jujur, ikhlas dalam perbuatan, adil, kasih sayang, ikhsan, mementingkan orang lain, tolong menolong, setia kawan, menjaga kemaslahatan umum, cinta tanah air, dan lainlain lagi bentuk akhlak yang mempunyai nilai sosial.

Ketauladanan dan contoh dalam pendidikan Islam yang berkaitan dengan kesolihan sosial ini dicontohkan oleh Rasulullah Saw. mulai dari masa kanak-kanak. Adapun contoh yang dicontokan oleh Rasuklullah saw. diantaranya yaitu:

1. Mengucapkan salam, salam berupa ucapan selamat bagi Islam dan merupakan kunci bagi hubungan yang bersifat kemanusiaan. Rasulullah saw. menhajarkan untuk menyebarkan salam.

2. Pada suatu kali seorang budak perempuan di Madinah datang untuk mengambil keperluan dengan kekuasaan Rasulullah. Maka beliau dan Rasulullah berjalan bersamanya dengan segala rasa simpati dan kasihan.

3. Rasulullah Saw. ditemani oleh Hasan atau Husain menuju masjid untuk hadir dalam shalat berjama'ah, sambil memperhatikan kondisi dan kehidupan sosial dengan apa yang mengelilinginya dari mainan-mainan anak-anak tersebut.

Pendidikan Islam merupakan perwujudan nilai-nilai islami dalam pribadi peserta didik yang diupayakan oleh pendidikan Islam. Pendidikan Islam harus mampu menjawab perkembangan zaman. Arus globalisasi yang mengalir semakin deras menyebar keberbagai negara Muslim tanpa terkecuali Indonesia secara tidak langsung memengaruhi sisi kehidupan umat Islam yang ada di daerah tersebut. Diharapkan pendidikan Islam dapat berperan maksimal dalam membangun kesolihan sosial.

Dalam Islam kesolihan sosial merupakan sesuatu keniscayaan. Islam mengajarkan bagaimana berperilaku atau bersosial dengan orang lain. Hal itu diatur di dalam Alquran dan hadis sebagai bentuk bahwa Islam mengajarkan kesolihan sosial dan tentunya harus diaplikasikan dalam pendidikan Islam. Salah satu contoh ayat Alquran tentang kesolihan sosial adalah firman Allah swt. yaitu:

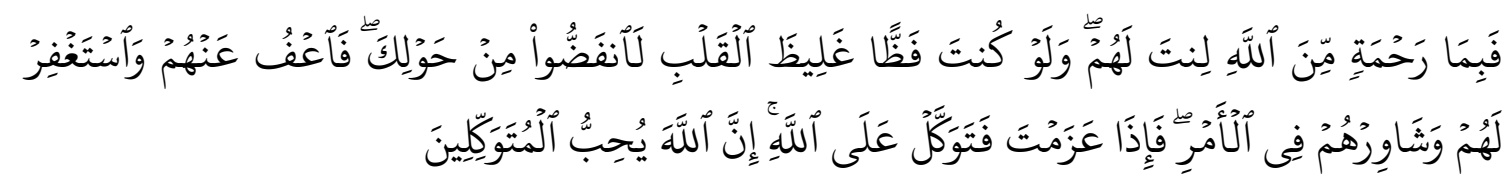

Artinya: Maka disebabkan rahmat dari Allah-lah kamu berlaku lemah lembut terhadap mereka. Sekiranya kamu bersikap keras lagi berhati kasar, tentulah mereka menjauhkan diri dari sekelilingmu. Karena itu maafkanlah mereka, mohonkanlah ampun bagi mereka, dan bermusyawaratlah dengan mereka dalam urusan itu. Kemudian apabila kamu telah membulatkan tekad, maka bertawakkallah kepada Allah. Sesungguhnya Allah menyukai orangorang yang bertawakkal kepada-Nya. 
Ayat di atas memiliki kekayaan materi pembahasan tentang kesolihan sosial dan salah satunya yaitu berkaitan dengan sikap lemah lembut. Bahwa sikap lemah lembut terhadap mereka hanyalah karena disebabkan rahmat yang besar dari Allah. Ada juga yang mengatakan, bahwa kata o di sini adalah partikel tanya, maknanya: maka dengan rahmat Allah yang mana kamu berlaku lemah lembut terhadap mereka? Di sini terkandung makna takjub. Namun pendapat ini jauh dari tepat, karena jika demikian, tentulah alif-nya pada kata ما dibuang. Ada juga yang mengatakan, bahwa maknanya adalah: Maka disebabkan rahmat dari Allah.

Menurut M. Quraish Shihab sekiranya engkau bersikap keras lagi berhati kasar...., mengandung makna bahwa engkau Muhammad, bukanlah seseorang yang berhati keras. Ini

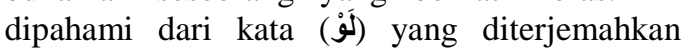
sekiranya. Kata ini digunakan untuk menggambarkan sesuatu yang bersyarat, tetapi syarat tersebut tidak dapat wujud. Kemudian Quraish mencontohkan dengan ilustrasi sebagai berikut "sekiranya ayah saya hidup, saya akan menamatkan kuliah." Karena ayahnya telah wafat, kehidupan yang diandaikannya pada hakikatnya tidak ada dan dengan demikian, tamat yang diharapkannya pun tidak mungkin wujud. Jika demikian, ketika ayat ini menyatakan sekiranya engkau bersikap keras lagi berhati keras, tentulah mereka menjauhkan diri dari sekelilingmu, tidak akan pernah terjadi.

Bagaimana mungkin orang yang hatinya keras, bahasanya kasar akan dijadikan pemimpin, akan diikuti dan ditaati. Perkataan yang lemah lembut akan menembus ke dalam hati, lebih cepat mendapat respon dan lebih memotivasi perbuatan taat. Hal tersebut memberikan pembeljaran yang bermakna bahwa tidak boleh kasar dan harus lemah lembut. Hal inilah yang diharapkan dioptimalisasi dalam pendidikan agama sehingga terbangun kesolihan sosial.

Pendidikan dan perubahan sosial saling bertautan satu dengan yang lain. Keduanya saling mempengaruhi, sehingga berdampak luas di masyarakat. Pendidikan dapat dijadikan sebagai agen pembaharu atau perubahan sosial dan sekaligus menentukan arah perubahan sosial yang disebut dengan pembangunan mesyarakat. Sedangkan perubahan sosial yang terjadi dalam masyarakat setiap kalinya dapat direncanakan dengan arah perubahan yang ingin dicapai. Namun perubahan sosial juga dapat terjadi setiap saat tanpa harus direncanakan terlebih dahulu disebabkan pengaruh budaya dari luar.

Pendidikan Islam bersifat memberikan stimulus kepada masyarakat agar memiliki sifat sosial. Pendidikan Islam dapat mengatasi problem-problem hak asasi manusia. Pendidikan Islam berwawasan HAM diharapkan sebagai upaya preventif bagi terjadinya kerusuhan massal, ketegangan sosial, dan pelanggaran HAM yang masih merajalela. Oleh karena itu, pendidikan Islam menjadi kunci bagi internalisasi nilai-nilai HAM.

Mewacanakan tentang pendidikan, maka tidak akan mungkin melepaskannya dari dinamika kehidupan sosial manusia yang senantiasa berkembang. Perkembangan sosial itulah yang pada akhirnya memperkaya konsepkonsep dalam usaha pengembangan dan perbaikan pendidikan. Sudah menjadi pendapat umum (common sense) bahwa pendidikan adalah rancangan kegiatan yang paling banyak berpengaruh terhadap perilaku seseorang dan masyarakat.

Pendidikan mempengaruhi masyarakat yang pada akhirnya terjadi perubahan sosial. Perubahan sosial sebagai bentuk inovasi yang terjadi berkaiatan dengan seluruh aspek kehidupan masyarakat yang bertujuan dalam meningkatkan kemakmuran. Pendidikan adalah sebagai proses yang dapat mengubah perilaku individu dalam konteks teori perubahan sosial akan mempunyai dampak terjadinya perubahan baik pada tingkat individu sebagai agen maupun tingkat kelembagaan yang mampu mengubah struktur sosial yang ada di masyarakat. Diharapkan pendidikan dalam perubahan sosial dapat menghasilakn generasi yang kritis serta solutif dalam menghadapi permasalahan sebagai bagian perubahan sosial masyarakat dewasa ini dan selanjutnya.

Pendidikan Islam hendaknya memperhatikan nilai-nilai sosial-budaya yang menjadi karakter bangsa Indonesia sebagai bangsa Timur yang ramah, toleran, mengedepankan musyawarah, serta tidak anti-perbedaan. Pendekatan tersebut dapat mejadi sintesis untuk menjawab sekelumit persoalan yang kerap muncul dalam sistem pendidikan, khususnya pendidikan Islam di Indonesia. Adapun bentuk kesolihan sosial yang diupayakan melalui peran penting pendidikan agama di madrasah antara lain yaitu:

1. Penanaman Dasar-dasar Psikis yang mulia

Dalam ajaran Islam menegaskan dasardasar pendidikan yang utama di dalam jiwa peserta didik baik kecil maupun besar, laki-laki maupun wanita, orang tua maupun pemuda, di atas dasar-dasar kejiwaan yang mulia dan mapan. Untuk menanamkan dasar-dasar psikis di dalam diri individu dan kelompok, Islam telah menetapkan arahan-arahan yang sangat berharga, demi tercapainya kesempurnaan pendidikan sosial, dari segi makna maupun tujuannya seperti takwa, ukhuwah, kasih saying, tolong menolong pemaaf dan lain-lain. 


\section{Memelihara Hak-hak Orang-orang} Lain

Hak-hak sosial terpenting yang harus disampaikan sebagai upaya pendidikan kepada anak agar ia dapat melaksanakannya secara baik adalah: hak terhadap kedua orang tua, hak terhadap saudara-saudara, hak terhadap guru, hak terhadap teman, hak terhadap orang besar. Melalui peran pendidikan agama di Madrasah hendaknya mengajarkan dan menanamkan semua itu kepada peserta didik.

3. Melaksanakan Adab-adab Sosial

Adab-adab sosial terkait erat dengan penanaman dasar-dasar psikis. Pelaksanaan adab-adab sosial secara umum berpijak pada landasan akidah iman dan takwa, persaudaraan, kasih sayang, lebih mengutamakan orang lain dan sopan santun, sehingga pendidikan sosial akan mencapai tujuannya yang paling tinggi. Bahkan ia akan tampil di masyarakat dengan perangai, akhlak dan interaksi yang sangat baik sebagai insan yang lurus, cerdas, bijak dan harmonis. Adapun diantara contoh dari adabadab sosial adalah adab makan dan minum, adab memberi salam, adab meminta izin, adab di dalam majelis, adab berbicara, adab bergurau, adab mengucapkan selamat, adab menjenguk orang sakit dan lain-lain.

\section{Pengawasan Dan Kritik Sosial}

Dasar sosial terpenting untuk membentuk perangai dan mendidik kehidupan sosial anak, adalah membiasakan anak sejak kecil untuk mengadakan pengawasan dan kritik sosial, membina setiap individu yang dipergauli, diikuti atau mengikuti, dan memberikan nasehat kepada setiap individu yang tampaknya menyimpang dan menyeleweng. Membiasakan anak sejak masa pertumbuhannya untuk melaksanakan kewajiban memerintahkan kebaikan dan mencegah kemungkaran, yang merupakan salah satu dasar Islam yang fundamental di dalam memelihara pendapat umum, memerangi kerusakan dan penyimpangan serta memelihara nilai, keteladanan dan akhlak dalam Islam.

Kesempurnaan sistem pendidikan Islam terlihat dalam sistem pendidikan yang dicontohkan oleh Rasulullah saw. dalam mendidik para shahabat yang telah menghasilkan generasi yang luar biasa. Generasi yang disebut-sebut sebagai generasi terbaik yang pernah ada. Tidak ada yang mampu menandinginya baik sebelum dan sesudah generasi shahabat tersebut. Ini menunjukkan bahwa peran pendidikan Islam apabila berjalan dengan baik akan menghasilkan kesoliham sosial dalam membangun generasi rahmatan lil 'alamin.

\section{KESIMPULAN}

Bangsa Indonesia adalah bangsa yang religius. Terbukti dengan adanya dukungan yang kuat terhadap penddidikan agama di lembaga-lembaga pendidikan. Usaha Pemerintah untuk meningkatkan mutu madrasah agar sejajar dengan sekolah umum yang setingkat. Usaha itu diwujudkan dengan keluarnya Surat Keputusan Bersama Tiga Menteri yang kemudian dikenal dengan SKB 3 M.

Dengan adanya penyempurnaan kurikulum pendidikan agama dan kombinasi dengan kurikulum kebutuhan masyarakat maka lembaga-lembaga pendidikan Islam baik di madrasah maupun pesantren dapat merespon tantangan dunia global yang semakin kompetitif. Nama dan citra madrasah dan pesantren tetap terjaga sebagai lembaga pendidikan Islam yang memiliki kontribusi besar bagi agama dan Negara dalam membangun kesolihan sosial. Ternyata alumnialumni madrasah dan pesantren mempunyai kompetensi. Banyak orangtua yang mengamanahkan anakanya ke madrasah dan pesantren serta lembaga-lembaga pendidikan Islam lainnya sebagai salah satu bukti kepercayaan terhadap peran agama di madrasah dalam membangun kesolihan sosial.

\section{DAFTAR PUSTAKA}

Al-Baruswi, Ismail Haqqi. Terjemah Tafsir Ruhul Bayan, Bandung: Diponegoro, 1996.

Al-Hasyimi, Abdul Hamid. Mendidik Ala Rasulullah, Terj. Ibn. Ibrahim, Jakarta: Pustaka Azzam, 2001.

Al-Rasyidin. Falsafah Pendidikan Islami: Membangun Kerangka Ontologi, Epistimologi dan aksiologi Praktik Pendidikan, Bandung: Citapustaka Media Perintis, 2012.

Anzizhan dan Syafaruddin. Visi Baru AlIttihadiyah, Medan: Perdana Publishing, 2015.

Asy-Syaukani, Imam. Tafsir Fathul Qadir 2, Jakarta: Buku Islsm Rahmatan, 2008.

Azra, Azyumardi, et.al. Varietes of Religious Authority: Changes and Challenges in $20^{\text {th }}$ Century Indonesian Islam, Singapore: ISEAS Publishing, 2010.

Daulay, Haidar Putra. Pemberdayaan Pendidikan Agama Islam di Sekolah, Jakarta: Kencana, 2016.

Daulay, Haidar Putra. Historisitas dan Eksistensi Pesantren dan Madrasah, Yogyakarta: Tiara Wacana, 2001.

Daulay, Haidar Putra. Pendidikan Islam di Indonesia, Medan: Perdana Publishing, 2012. 
Daulay, Haidar Putra. Sejarah Pertumbuhan dan Pembaruan Pendidikan Islam di Indonesia, Jakarta: Kencana, 2009.

Depdiknas, Kurikulum 2004 Standar Kompetensi Pendidikan Agama Islam Sekolah Menengah Atas dan Madrasah Aliyah, Jakarta: Pusat Kurikulum Balitbang Depdiknas, 2003.

Dhofier, Zamakhsyari. Tradisi Pesantren: Studi tentang Pandangan Hidup Kiyai, Jakarta: LP3ES, 1981.

Ghazali, M. Bahri. Pendidikan Pesantren Berwawasan Lingkungan: Kasus Pondok Pesantren An- Nuqayah Guluk-Guluk Sumenep, Madura, Jakarta: Pedoman Ilmu, 2001.

Hasbullah, Kapita Selekta Pendidikan Islam di Indonesia, Jakarta: PT Raja Grafindo Persada, 1996.

Huda, Miftahul. Peran Pendidikan Islam Terhadap Perubahan Sosial dalam Edukasia: Jurnal Penelitian Pendidikan Islam, Vol. 10, No. 1, Februari 2015.

Kartasapoetra, G. dan Hartini. Kamus Sosiologi dan Kependudukan, Jakarta: Bumi Aksara, 2007.

Lubis, Lahmuddin dan Elfiah Muchtar, Pendidikan Agama: Dalam Perspektif Islam, Kristen dan Budha, Bandung: Citapustaka Media Perintis, 2013.

Lubis, Lahmuddin. Konseling dan Terapi Islami, Medan: Perdana Publishing, 2016.

Lubis, Lahmuddin. Landasan Formal Bimbingan Konseling di Indonesia, Bandung: Ciptapustaka Media Perintis, 2011.

M. Arifin, Kapita Selekta Pendidikan Islam dan Umum, Jakarta:Bumi Aksara,1991.

Mastuhu. Dinamika Sistem Pendidikan Pesantren: Suatu Kajian tentang Unsur dan Nilai Sistem Pendidikan Pesantren, Jakarta: INIS, 1994.

Masyhud, Sulthon, dkk., Manajemen Pondok Pesantren, Jakarta: Diva Pustaka, 2004.

Muhaimin, Pengembangan Kurikulum Pendidikan Agama Islam di Sekolah, Madrasah dan Perguruan Tiggi, Jakarta: PT. RajaGrafindo Persada, 2012.
Muhammad Irsad, Pengembangan Kurikulum Pendidikan Agama Islam Di Madrasah (Studi Atas Pemikiran Muhaimin), Jurnal Iqra', Vol. 2, No. 1, November 2016 ISSN: 2527-4449, h. 248-249.

Mujib, A. et. al., Intelektualisme Pesantren: Potret Tokoh dan Cakrawala Pemikiran di Era Perkembangan Pesantren, Jakarta: Diva Pustaka, 2006.

Mujib, Abdul. Ilmu Pendidikan Islam, Jakarta: Kencana Penada Media, 2006.

Rais, Amien. Cakrawala Islam: Antara Cita dan Fakta, Bandung: Mizan,1989.

Rohman, Miftahur dan Hairudin. Konsep Tujuan Pendidikan Islam Perspektif Nilai-nilai Sosial-kultural dalam AlTadzkiyyah: Jurnal Pendidikan Islam, Volume 9, Edisi I 2018.

Shaleh, Abdul Rachman. Pendidikan Agama \& Pembangunan Watak Bangsa Jakarta: PT Raja Grafindo Persada, 2006.

Shihab, M. Quraish. Tafsir al-Mishbah: Pesan, Kesan, dan Keserasian al-Qur'an, Vol. 2, Jakarta: Lentera Hati, 2011.

Suwendi. Sejarah dan Pemikiran Pendidikan Islam (Jakarta: Rajawali Pers, 2002), h. 133.

Suyanto, Agus. Psikologi Umum, Jakarta : Aksara Baru, 1983.

Syafaruddin, dkk., Ilmu Pendididkan Islam: Melejitkan Potensi Budaya Umat Jakarta: Hijri Pustaka Utama, 2014.

Tafsir, Ahmad. Cakrawala Pemikiran Pendidikan Islam, Bandung: Mimbar Pustaka, 2014.

Thoha, Chabib., dkk, Metodologi Pengajaran Agama, Yogyakarta: Pustaka Pelajar, 1999.

Tim Direktorat Jenderal Pembinaan Kelembagaan Agama Islam. Profil Pondok Pesantren Mu'adalah, Jakarta: Direktorat Pendidikan Keagamaan dan Pondok Pesantren Departemen Agama, 2004.

Wahjoetomo, Perguruan Tinggi Pesantren, Pendidikan Alternatif Masa Depan, Jakarta: Gema Insani Press, 1997. 